\title{
Extreme obesity: sociodemographic, familial and behavioural correlates in The Netherlands
}

\author{
Maruschka P Merkus, Lisbeth M H Mathus-Vliegen, Catja Broekhoff, \\ Astrid M P Heijnen
}

\begin{abstract}
Study objective - To investigate the relationship between sociodemographic, behavioural, and family characteristics and the body mass index (BMI) (weight (kg)l height $\left(\mathbf{m}^{2}\right)$ ) of extremely obese people.

Design - Self reported sociodemographic, behavioural, and familial characteristics and weight and height were obtained by postal questionnaire.

Participants and setting - Adult, obese Dutch people who, on their own initiative, contacted our hospital for information on obesity treatment were sent a questionnaire. A total of 244 of 690 subjects had returned the questionnaire within the stated period of 80 days. Due to missing data 19 subjects could not be included in this analysis, leaving 191 women and 34 men.

Main results - In women the $\mathrm{BMI}$ seemed to be significantly inversely associated with the level of education of the partner, the number of cups of coffee consumed, and number of cigarettes smoked a day. In addition, the BMI of women was positively related to BMI of their mothers. Together these variables explained $18 \cdot 0 \%$ of the total variation in BMI. In men none of the selected variables was associated with their BMI.

Conclusion - As the selected variables explained almost one fifth of the total variation in BMI, the impact of sociodemographic, familial, and behavioural factors should have more recognition in strategies aimed at reducing obesity.
\end{abstract}

( $\mathcal{F}$ Epidemiol Community Health 1995;49:22-27)

Based on calculations of the body mass index (BMI, weight $(\mathrm{kg})$ divided by the square of height (m)), $17 \%$ of the Dutch population are overweight $\left(\mathrm{BMI} \geq 27 \mathrm{~kg} / \mathrm{m}^{2}\right.$ ) and $5 \%$ are extremely obese (BMI $30.0-39.9 \mathrm{~kg} / \mathrm{m}^{2}$ ). ${ }^{1}$ Overweight and obesity are important risk factors for various chronic diseases such as cardiovascular diseases, diabetes mellitus, gall stones, gout, certain malignancies, ventilatory and musculoskeletal disorders, and psychosocial dysfunction. ${ }^{2-8}$ Research on the origins of obesity has focussed mainly on the (patho-)physiological mechanisms. Yet, a number of studies have shown the existence of sociodemographic, familial (hereditary versus environmental), and behavioural influences on the onset of obes- ity. ${ }^{9-22}$ Most of these studies concerned representative samples of the general population, consisting principally of normal weight to moderately obese people. ${ }^{9-172021}$ There are few data on the impact of these variables on extreme obesity. As we had access to a large population of severely (BMI $30 \cdot 0-39.9 \mathrm{~kg} / \mathrm{m}^{2}$ ), morbidly (BMI $40 \cdot 0-49.9 \mathrm{~kg} / \mathrm{m}^{2}$ ), and super morbidly (BMI $\geq 50 \mathrm{~kg} / \mathrm{m}^{2}$ ) obese persons, we performed a study on the relationship between sociodemographic, familial, and behavioural characteristics and the degree of obesity.

\section{Methods}

POPULATION AND STUDY DESIGN

A short, late evening medical television broadcast about intragastric balloon treatment by one of us $(\mathrm{M}-\mathrm{V})$ in October 1986 resulted in 1000 obese individuals contacting our hospital. Five whole-day meetings were organised to give information about the complex aetiology and treatment of obesity and the place of intragastric bubble therapy. Those who attended the meeting were asked to complete a questionnaire with items on weight, height, medical and familial history, education, and occupation of the subject, partner, and father. They were also asked to complete an eating behaviour questionnaire. ${ }^{23}$

In May 1990, a total of 713 individuals (562 women and 151 men) who completed the 1986 questionnaires, and who had not participated in any weight loss programme in our centre, received a follow up questionnaire. This inquiry consisted of questions about their present weight and height and that of their family members, self reported illnesses, weight reduction therapies, use of anorectic drugs, and sociodemographic and behavioural characteristics. In addition, information on personality traits was obtained. ${ }^{24}$

In the present report only the sociodemographic, behavioural and family line analyses of the BMI are described.

SOCIODEMOGRAPHIC, BEHAVIOURAL, AND FAMILY CHARACTERISTICS

The sociodemographic parameters considered were marital status, education, and occupation of the subject and of his/her partner and father, and parity and the size of the family of origin. Marital status was divided into married and unmarried. People who were cohabiting were classified as married. The unmarried category comprised never married, separated, divorced, and widowed. Parity was divided into four 

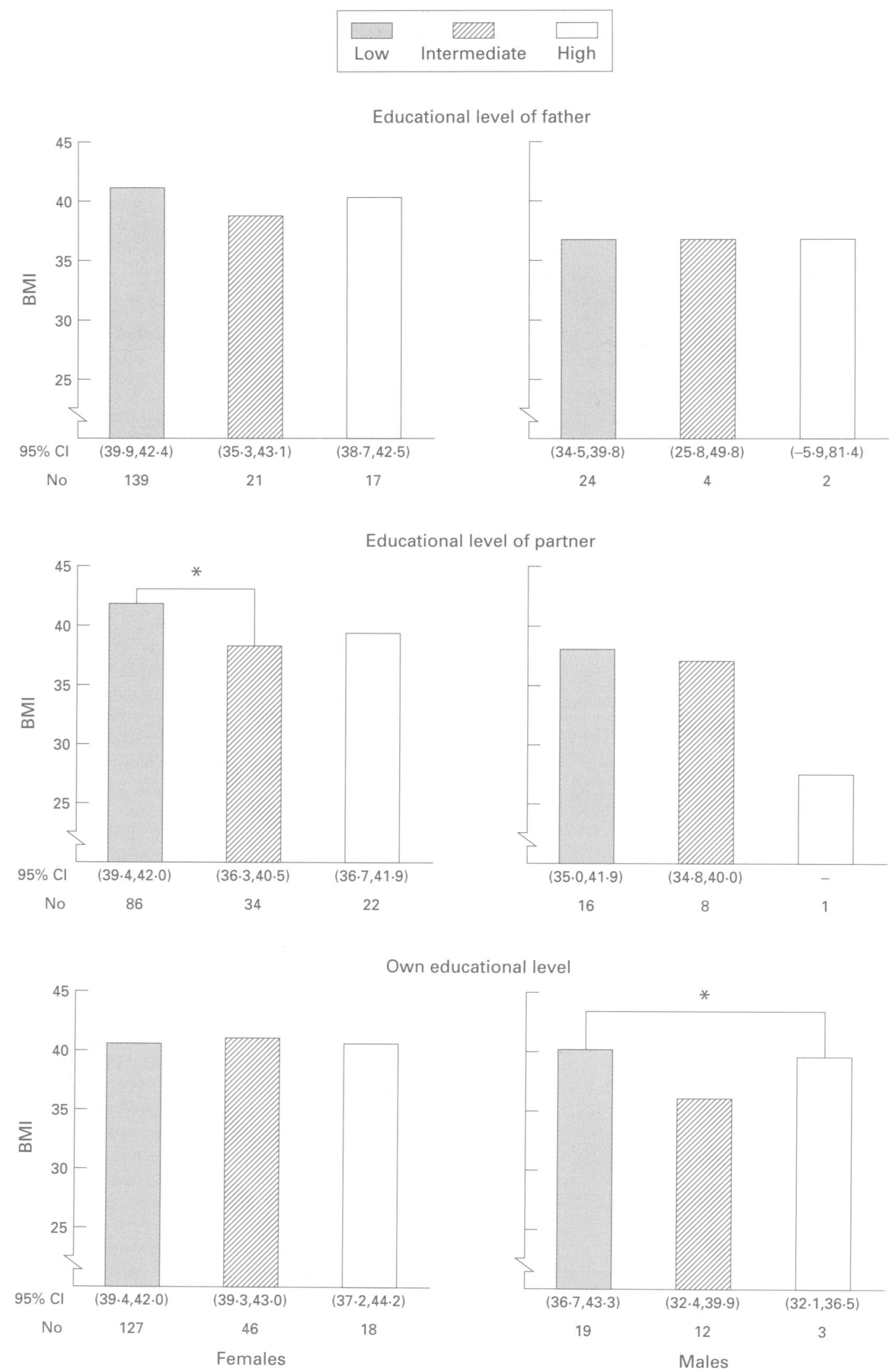

Figure 1 Mean body mass index (in $\mathrm{kg} / \mathrm{m}^{2}$ ) in women and men according to their own educational level and those of their partner and father.

categories: $0,1,2$, and 3 or more children. Size of the family of origin was categorised into three levels: $1-2,3-4$, and 5 or more children.

Three levels of education were distinguished: (1) primary school, low secondary school level and low vocational training (low level); (2) intermediate and high secondary school level and intermediate vocational training (in- termediate level); and (3) university and high vocational training (high level). Occupational status was divided into four categories: (1) unemployed; (2) blue collar workers and housewives (low status); (3) self employed tradesmen, small business men, farmers, and white collar workers (intermediate status); and (4) professional workers (high status). 
Table 1 Body mass index (BMI) of the study population in relation to category of sociodemographic and

behavioural variables

\begin{tabular}{|c|c|c|c|}
\hline \multirow[b]{2}{*}{ Variable } & \multicolumn{3}{|c|}{$B M I$} \\
\hline & No & Mean & $(95 \% C I)$ \\
\hline \multicolumn{4}{|l|}{ (A) Women } \\
\hline \multicolumn{4}{|l|}{ Marital status: } \\
\hline Married & 124 & $40 \cdot 3$ & $(39 \cdot 0,41 \cdot 7)$ \\
\hline Unmarried & 65 & $41 \cdot 7$ & $(40 \cdot 1,43 \cdot 4)$ \\
\hline \multicolumn{4}{|l|}{ Parity: } \\
\hline 0 & 55 & $40 \cdot 3$ & $(38 \cdot 5,42 \cdot 1)$ \\
\hline 1 & 37 & $41 \cdot 5$ & $(38 \cdot 9,44 \cdot 0)$ \\
\hline 2 & 61 & $40 \cdot 2$ & $(38 \cdot 2,42 \cdot 3)$ \\
\hline$\geq 3$ & 38 & $41 \cdot 9$ & $(39 \cdot 8,44 \cdot 0)$ \\
\hline \multicolumn{4}{|c|}{ Size of family of origin: } \\
\hline$\leq 2$ children & 66 & $41 \cdot 5$ & $(40 \cdot 0,43 \cdot 0)$ \\
\hline 3-4 children & 65 & $39 \cdot 0$ & $(37 \cdot 3,40 \cdot 7)$ \\
\hline$\geq 5$ children & 52 & $42 \cdot 1$ & $(39 \cdot 8,44 \cdot 4)$ \\
\hline \multicolumn{4}{|l|}{ Coffee consumption: } \\
\hline 0 cups $/ \mathrm{d}$ & 51 & $40 \cdot 6$ & $(38 \cdot 8,42 \cdot 4)$ \\
\hline $1-3 \mathrm{cups} / \mathrm{d}$ & 45 & $43 \cdot 2$ & $(41 \cdot 0,45 \cdot 3)$ \\
\hline $4-6 \mathrm{cups} / \mathrm{d}$ & 60 & $41 \cdot 0$ & $(39 \cdot 2,42 \cdot 7)$ \\
\hline$\geq 7 \mathrm{cups} / \mathrm{d}$ & 34 & $37 \cdot 5^{*}$ & $(34 \cdot 7,40 \cdot 3)$ \\
\hline \multicolumn{4}{|l|}{ Alcohol consumption: } \\
\hline No & 118 & $41 \cdot 5$ & $(40 \cdot 2,42 \cdot 9)$ \\
\hline Yes & 68 & $39 \cdot 7$ & $(38 \cdot 1,41 \cdot 3)$ \\
\hline \multicolumn{4}{|l|}{ Smoking status: } \\
\hline 0 cigarettes $/ \mathrm{d}$ & 114 & $41 \cdot 0$ & $(39 \cdot 7,42 \cdot 3)$ \\
\hline $1-15$ cigarettes $/ \mathrm{d}$ & 41 & $42 \cdot 1$ & $(39 \cdot 7,44 \cdot 6)$ \\
\hline$\geqslant 16$ cigarettes $/ \mathrm{d}$ & 33 & $38 \cdot 4$ & $(36 \cdot 0,40 \cdot 8)$ \\
\hline \multicolumn{4}{|l|}{ (B) $\mathrm{Men}$} \\
\hline \multicolumn{4}{|l|}{ Marital status: } \\
\hline Married & 21 & $39 \cdot 4$ & $(36 \cdot 5,42 \cdot 4)$ \\
\hline Unmarried & 13 & $36 \cdot 0$ & $(32 \cdot 1,39 \cdot 9)$ \\
\hline \multicolumn{4}{|l|}{ Parity: } \\
\hline 0 & 10 & 38.9 & $(32 \cdot 1,45 \cdot 3)$ \\
\hline 1 & 5 & $34 \cdot 3$ & $(29 \cdot 8,38 \cdot 9)$ \\
\hline 2 & 11 & $39 \cdot 1$ & $(35 \cdot 1,43 \cdot 1)$ \\
\hline$\geq 3$ & 8 & $38 \cdot 1$ & $(33 \cdot 6,42 \cdot 7)$ \\
\hline \multicolumn{4}{|c|}{ Size of family of origin: } \\
\hline$\leq 2$ children & 8 & $37 \cdot 8$ & $(29 \cdot 6,46 \cdot 1)$ \\
\hline 3-4 children & 19 & $38 \cdot 6$ & $(36 \cdot 0,41 \cdot 3)$ \\
\hline$\geq 5$ children & 6 & $37 \cdot 4$ & $(30 \cdot 9,43 \cdot 8)$ \\
\hline \multicolumn{4}{|l|}{ Coffee consumption: } \\
\hline $0 \mathrm{cups} / \mathrm{d}$ & 5 & $44 \cdot 8$ & $(34 \cdot 7,54 \cdot 9)$ \\
\hline $1-3$ cups $/ \mathrm{d}$ & 6 & $48 \cdot 2$ & $(28 \cdot 0,68 \cdot 3)$ \\
\hline $4-6 \mathrm{cups} / \mathrm{d}$ & 10 & $42 \cdot 2$ & $(36 \cdot 7,47 \cdot 7)$ \\
\hline$\geq 7 \mathrm{cups} / \mathrm{d}$ & 12 & $42 \cdot 9$ & $(38 \cdot 0,47 \cdot 8)$ \\
\hline \multicolumn{4}{|l|}{ Alcohol consumption: } \\
\hline No & 15 & $37 \cdot 2$ & $(33 \cdot 3,41 \cdot 1)$ \\
\hline Yes & 16 & $38 \cdot 6$ & $(35 \cdot 9,41 \cdot 3)$ \\
\hline \multicolumn{4}{|l|}{ Smoking status: } \\
\hline 0 cigarettes $/ \mathrm{d}$ & 23 & $39 \cdot 3$ & $(36 \cdot 3,41 \cdot 9)$ \\
\hline $1-15$ cigarettes $/ \mathrm{d}$ & 4 & $34 \cdot 8$ & $(28 \cdot 6,41 \cdot 0)$ \\
\hline$\geqslant 16$ cigarettes $/ \mathrm{d}$ & 7 & $36 \cdot 8$ & $(29 \cdot 8,40 \cdot 4)$ \\
\hline
\end{tabular}

Table 2 Correlation of the body mass index (BMI) of the cases with the BMI of their family members

\begin{tabular}{llllll}
\hline & \multicolumn{2}{l}{$B M I\left(\mathrm{~kg} / \mathrm{m}^{2}\right)$} & \\
\cline { 2 - 3 } \cline { 5 - 6 } \cline { 5 - 6 } & \multicolumn{2}{l}{ Women } & & \multicolumn{2}{l}{ Men } \\
\cline { 2 - 3 } \cline { 5 - 6 } & $r^{*}$ & No & & $r^{*}$ & No \\
\hline BMI father & 0.05 & 158 & & 0.19 & 28 \\
BMI mother & $0.18^{*}+$ & 166 & & 0.15 & 28 \\
BMI partner & 0.09 & 125 & & 0.21 & 22 \\
\hline
\end{tabular}

* Correlation coefficient.

$+\mathrm{p}<0.05$.

The behavioural variables comprised smoking and consumption of coffee and alcohol. Smoking status was based on cigarettes as only three people reported that they smoked cigars or a pipe. Smokers were grouped into: $0,1-15$, and 16 or more cigarettes/day. Alcohol consumption was divided into: $0,1-8,9-16$, and 17 or more units/week. Since the numbers in the two highest categories were small, the second, third, and fourth categories were combined and only "yes" or "no" alcohol consumption was considered. Consumption of coffee was grouped according to: $0,1-3,4-6$, and 7 or more cups/day. Being fifth in the world ranking of coffee consuming countries $(8 \mathrm{~kg}$ per person per year), with tea consumption
Table 3 Multiple regression analysis of the univariate significant associated sociodemographic, behavioural and family line characteristics with body mass index in the female study population

\begin{tabular}{|c|c|c|c|}
\hline Variable & $B^{*}$ & $p$ & $R^{\prime} \dagger$ \\
\hline $\begin{array}{l}\text { Educational level of } \\
\text { partner }\end{array}$ & $-0 \cdot 25$ & 0.003 & $18.0 \%$ \\
\hline $\begin{array}{l}\text { Size of family of origin: } \\
\quad \leq 2 \text { v } 3-4 \\
\geq 5 \text { v } 3-4\end{array}$ & $\begin{array}{l}0 \cdot 04 \\
0.08\end{array}$ & $\begin{array}{l}0.678 \\
0.377\end{array}$ & \\
\hline Coffee consumption & $-0 \cdot 28$ & $0 \cdot 001$ & \\
\hline $\begin{array}{l}\text { Smoking status: } \\
\geq 16 v 0 \\
1-15 v 0\end{array}$ & $\begin{array}{r}-0.24 \\
0.12\end{array}$ & $\begin{array}{l}0 \cdot 007 \\
0.171\end{array}$ & \\
\hline BMI mother & $0 \cdot 21$ & 0.013 & \\
\hline
\end{tabular}

* Standardised regression coefficient.

† Adjusted $\mathrm{R}^{2}$.

lagging one third behind, only coffee consumption was considered..$^{2526}$

In addition, the BMI of the subjects were related to those of their father, mother, and partner.

\section{STATISTICAL ANALYSIS}

Differences in BMI between the categories of the selected variables were analysed by one way analysis of variance and where the data were not normally distributed or there was inequality of variances the Kruskall-Wallis test was used. To pinpoint where the differences between the categories of a variable lie, the Student's $t$ test or the Mann-Whitney U test with correction for multiple comparisons by way of Bonferroni's correction method were used.

The association between the BMI of the subjects and those of family members were assessed by Pearson's correlation coefficient. Where data were not normally distributed the Spearman rank correlation coefficients were calculated.

To determine the extent to which statistically significantly associated variables contributed to the BMI independently of each other, stepwise multiple linear regression analysis was performed. Whenever doubt existed about a linear relationship between the BMI and the explanatory variable - that is, there was no significant correlation coefficient - the variable was introduced as a dummy variable. To control for the possible physiological effects of age and smoking status on weight, all multivariate analyses were adjusted for these factors.

The statistical analyses were carried out using SPSS $/ P C+$ software. All analyses were carried out for men and women separately. Two sided values of $p<0.05$ were considered statistically significant.

\section{Results}

Within the fixed term of 80 days, 244 of 713 questionnaires were returned. In addition, 23 forms were sent back as undeliverable. Thus, the response rate for the 1990 questionnaire was $35 \cdot 6 \%$ (244 of $690 * 100)$. Due to missing data, 19 forms were unusable and excluded from the present analysis, leaving a total of 225 persons in the study population, 191 women $(84.9 \%)$ and 34 men $(15.1 \%)$. 

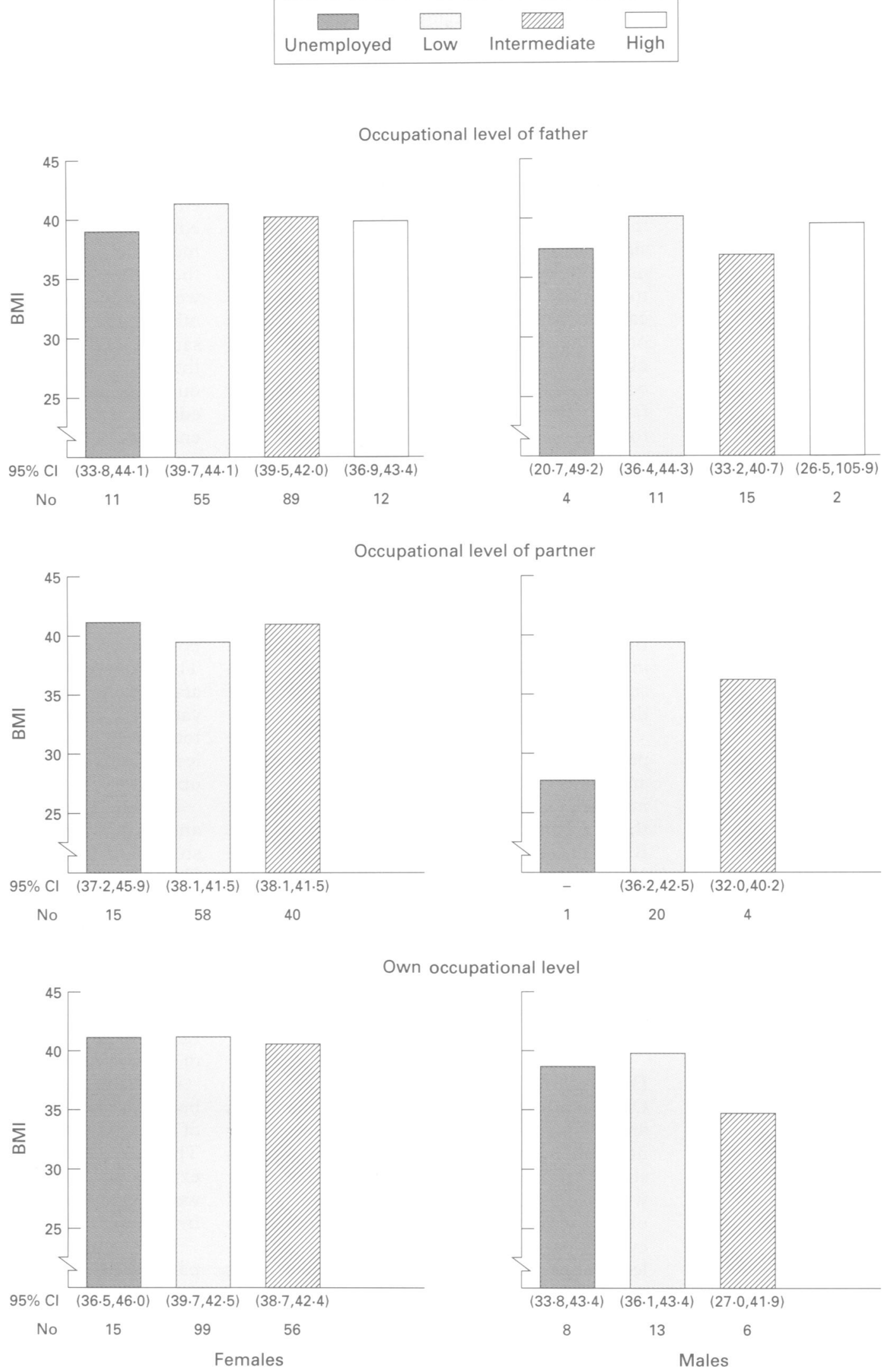

Figure 2 Mean body mass index (in $\mathrm{kg} / \mathrm{m}^{2}$ ) in women and men according to their own occupational status and those of their partner and father.

The mean (SD) age of the women was $38 \cdot 7$ $(11 \cdot 4)$ years and the mean BMI was $40 \cdot 8(7 \cdot 2)$ $\mathrm{kg} / \mathrm{m}^{2}$. Corresponding values for the $34 \mathrm{men}$ were $44.2(10.4)$ years and $38.1(6.6) \mathrm{kg} / \mathrm{m}^{2}$, respectively. The differences in BMI and age between women and men seemed statistically significant. Among women the prevalences of severe, morbid, and super morbid obesity were $41.4,41 \cdot 3$, and $12.0 \%$ respectively. Among men corresponding prevalences of $50 \cdot 0,32 \cdot 4$, and $2.9 \%$ were found.

In tables $1 A$ and $B$ and figures 1 and 2 the numbers of women and men and their BMI in each category of the selected sociodemographic 
and behavioural variables are displayed. In women, a significant effect of educational level of the partner, size of the family of origin, and level of consumption of coffee on BMI was found. Multiple comparisons between the categories of these variables showed a significantly lower BMI for women with a partner educated to an intermediate level compared with women with a less educated partner. Women who drank more than seven cups of coffee a day had a significantly lower BMI than those who drank one to three cups of coffee a day. With regard to the size of the family of origin, no two categories differed significantly from each other. No significant relationships were found between BMI of the women and their own occupational status or that of their partner or father. The consumption of alcohol was not found to be related to their BMI.

Though no overall effect of their own educational level on BMI was detected among men, those with a high educational level showed a significantly lower BMI than those with a low educational level. None of the other factors considered seemed to be associated with BMI among men.

The correlations of BMI of the subject with BMI of his/her family members are displayed in table 2. Only the BMI of the mother seemed significantly positively associated with $\mathrm{BMI}$ of the female subject $(r=0 \cdot 18)$.

In the women the educational level of the partner, consumption of coffee, smoking status, and the BMI of the mother predicted the BMI independently of each other (table 3). Together they explained $18.0 \%$ of the total variability in BMI. The effect of their own educational level on the BMI of the men disappeared when adjustments for age and smoking were made. As no significant linear correlation was found between smoking status and BMI, as well as between the size of the family of origin and BMI (results not shown), both were introduced into the regression analysis as dummy variables.

\section{Discussion}

Obesity affects women more often than men and the preponderance of women is especially noticeable in the super obese category. In this study five of every six obese subjects were women and the prevalence of super morbid obesity was four times higher in women. On evolutionary grounds, natural and sexual selection may play a role, making women resistant to famine and subject to obesity in times of abundant food supplies or feasts. Socioculturally, women differ considerably from men, but the relevance of this to extreme obesity remains largely unknown. ${ }^{27}$ We therefore studied the sociodemographic, familial, and behavioural correlates of extreme obesity, realising the limitations of the study as a result of the composition of the population and the self reported character of the data.

In the women in this study, a strong independent inverse relationship was observed between BMI and the educational level of the partner. No such relationship was found with regard to their own educational level. Similar results were obtained by Rimm and Rimm ${ }^{19}$ and Shah et $a l^{21}$ in their female populations. Several other studies, however, observed a clear inverse relationship between own educational level and the BMI of women ${ }^{1012141720}$ but did not consider the educational level of the partner. The discrepancy between these studies may be explained by population related differences and the different criteria used to classify education and BMI. In this respect it is remarkable that both our study population and the one of Rimm and Rimm ${ }^{19}$ concerned overweight women wishing to lose weight, while the other study populations consisted of random samples of the general population. Furthermore, the fact that almost all the women in our study belonged to the low and intermediate educational level, whereas significant differences in BMI were primarily found between women of the highest and lowest levels of education, may have contributed to the discrepancy. ${ }^{12141620}$ Previous studies observed either a positive $\mathrm{i}^{1416}$ or inverse $\mathrm{e}^{10121520}$ association between own educational level and BMI among men. In our study, however, after adjustment for age and smoking, no such relationship was found. The small number of men in our study population might be a possible explanation. This may also hold true for the absence of an association between BMI and any of the other variables considered among the men. Alternatively, it may suggest that male obesity is less sensitive to social pressures than female obesity. ${ }^{27}$

Like the female populations of Baecke et al ${ }^{10}$ and Shah et al, ${ }^{21}$ the occupational status of our study females did not determine their BMI. However, Baecke et $a l^{10}$ observed a significant effect of occupational status of the female's father. As their population consisted of young adult women between the ages of 19 and 31 years, the characteristics of the family of origin could still be expected to be of more significance. In accordance with our results, Baecke et $a l^{10}$ did not find a significant influence of the size of the family of origin on the BMI.

Unlike the common experience that women become fatter after each pregnancy, the BMI of the present women was not related to parity. The effect of parity on BMI may be lost in extreme obesity, as significant effects of parity were found among women with a BMI ranging from normal to moderate overweight. ${ }^{101728}$

In previous studies, in addition to the childparent BMI associations, associations between the BMI of spouses have been found, prompting the question whether family obesity is more a matter of shared environment than of shared genes. $^{29-32}$ The only family BMI association found in our study was one between women and their mothers. As our population primarily comprised extremely obese people, in contrast to the former study populations, this might suggest that extreme obesity is more a matter of genetics than moderate obesity. However, as we investigated mainly people seeking to lose weight, these findings may not be generalisable. Moreover, our observations also contradict the suggested selective mating as an alternative explanation of the association between the BMI 
of the spouses. ${ }^{102930}$ In addition, no effect of marital status on BMI was observed, equivalent to results of some former studies. ${ }^{2021}$ Other studies, however, observed that married people were of higher weight than unmarried persons. ${ }^{11217}$ Not only the existence but also the direction of the association remains to be clarified, as Jeffery et $a l^{15}$ observed lowest rates of marriage in the lowest and highest quintiles of weight distribution.

Our observation of an inverse relationship between the BMI and the level of consumption of coffee and smoking accords with the supposed thermogenetic effect of caffeine and smoking. ${ }^{3344}$ On the contrary, Shah et al ${ }^{11}$ reported a positive association between caffeine intake and BMI but calory intake from milk and sugar intake along with coffee and energy from soft drinks were not controlled for.

Almost one fifth of the total variation in the women's BMI was explained by sociodemographic, familial, and behavioural characteristics. Although we acknowledge that other factors, such as heredity, are important in the aetiology of extreme obesity, and though we recognise the limits of our study, we still believe that the above mentioned characteristics should have more of a role in antiobesity strategies, as environmental influences can be modified. Since extreme obesity, once established, can hardly be treated effectively in the long term, anti-obesity strategies should focus on prevention by promoting healthy dietary habits and habitual physical activity. Information services should take advantage of findings such as ours and try to reach citizens at home, at work, at primary and low vocational training schools, at welfare centres, and women's unions and associations.

1 Centraal Bureau voor de Statistiek. Maandbericht gezondheidsstatistiek. The Hague: Central Bureau for Statzondheidsstatistie

2 Bray GA. Complications of obesity. Ann Intern Med 1985; 103:1052-62.

3 Imeson JD, Haines AP, Meade TW. Skinfold thickness, body mass index and ischemic heart disease. $f$ Epidemiol Community Health 1989;43:223-7.

4 Larsson B, Bjorntorp P, Tibblin G. The health consequences of moderate obesity. Int $\mathcal{F}$ Obesity 1981;5:97-116.

5 Negri E, Pagano R, Decarli A, La Vecchia C. Body weight and the prevalence of chronic diseases. $f$ Epidemiol Com munity Health 1988;42:24-9.

6 Seidell JC, de Groot LCPGM, van Sonsbeek JLA, Deurenberg P, Hautvast JGAJ. Associations of moderate and
severe overweight with self-reported illness and medical care in Dutch adults. Am f Public Health 1986;76:264-9.

7 Itallie van TB. Obesity: adverse effects on health and longevity. Am $\mathcal{F}$ Clin Nutr 1979;32:2723-33.

8 Itallie van TB. Health implications of overweight and obesity in the United States. Ann Intern Med 1985;103:983-8.

9 Ashwell M, North WRS, Meade TW. Social class, smoking and obesity. $B M \mathcal{F}$ 1978;ii: 1466-7.

10 Baecke JAH, Burema J, Frijters JER, Hautvast JGAJ, WielWetzels van de WAM. Obesity in young adults: I, Sociodemographic variables and body mass index. Int $\mathcal{f}$ Obesity 1983;7:1-12.

11 Croft JB, Strogatz DS, James SA, Keenan NL, Ammerman AS, Malarcher AM, Haines PS. Socioeconomic and behavioral correlates of body mass index in black adults: the Pitt County study. Am $\mathcal{f}$ Public Health 1992;82:821-6.

12 Evers S. Economic and social factors associated with obesity in adult Canadians. Nutrition Research 1987;7:3-13.

13 Fehily AM, Phillips KM, Yarnell JWG. Diet, smoking, social class, and body mass index in the Caerphilly heart disease study. Am f Clin Nutr 1984;40:827-33.

14 Garn SM, Bailey SM, Cole PE, Higgins TT. Level of education, level of income, and level of fatness in adults. Am F Clin Nutr 1977;30:721-5.

15 Jeffery FW, Forster JL, Folsom AR, Luepker RV, Jacobs JR, Blackburn $\mathrm{H}$. The relationship between social status and body mass index in the Minnesota health program. Int $f$ Obesity 1989;13:59-67.

16 Kohrs MB, Wang LL, Eklund D, Pualsen B. The association of obesity with socioeconomic factors in Missouri. $A m \mathcal{F}$ Clin Nutr 1979;32:2120-8.

17 Noppa H, Bengtsson C. Obesity in relation to socioeconomic status. A population study of women in Göteborg, Sweden.
f Epidemiol Community Health 1980;34:139-42.

18 Oken B, Hartz A, Giefer E, Rimm AA. Relation between socioeconomic status and obesity changes in 9046 women. socioeconomic status and o
Prev Med 1977;6:447-53.

19 Rimm IJ, Rimm AA. Association between socioeconomic status and obesity in 59,556 women. Prev Med 1974;3 543-72

20 Rissanen Am, Heliovaara M, Knekt P, Reunanen A, Aromaa A. Determinants of weight gain and overweight in adult Finns. Eur $\mathcal{F}$ Clin Nutr 1991;45:419-30.

21 Shah M, Jeffery RW, Hannan PJ, Onstad L. Relationship between socio-demographic and behaviour variables, and body mass index in a population with high-normal blood pressure: hypertension prevention trial. Eur $\mathcal{F}$ Clin Nutr 1989;45:583-96.

22 Sobal J, Stunkard AJ. Socioeconomic status and obesity: a review of the literature. Psychol Bull 1989;105:260-75.

23 Van Strien T, Frijters JER, Bergers GPA, Defares PB. The Dutch eating behaviour questionnaire (DEBQ) for assessment of restrained, emotional and external eating behaviour. International fournal of Eating Disorders 1986; behaviour.

24 Stichting Werkgroep Nederlandse Persoonlijkheids Vragenlijst. Nederlandse persoonlijkheids vragenlijst. Lisse: Swets Test Services, 1974

25 Dekker P, Van het Reve CGM, Den Hartog AP. Koffiegebruik en koffiegewoonten in Nederland. Voeding 1993 54:6-10.

26 Netherlands Nutrition Council. Nutrition, food and health in the Netherlands. The Hague: Netherlands Nutrition Council, 1990:9-18.

27 Hoyenga KB, Hoyenga KT. Gender and energy balance: sex differences in adaptation for feast and famine. Physiology and Behaviour 1982;28:545-63.

28 Heliövaara M, Aromaa A. Parity and obesity. 7 Epidemiol Community Health $1981 ; 35: 197$. Parity and

29 Garn SM, Clark DC. Trends in fatness and the origins of obesity. Pediatrics 1976;57:443-56.

30 Garn SM. Family-line and socio-economic factors in fatness and obesity. Nutr Rev 1986;44:381-6.

31 Bray GA. The inheritance of corpulence. In: Cioffi A ed. The body weight regulatory system: normal and disturbed mechanisms. New York: Raven Press, 1981.

32 Garn SM, Sulivan TV, Hawthorne VM. Fatness and obesity of the parents of obese individuals. Am F Clin Nutr 1989; 50:1308-13.

33 Dulloo AG, Geissler CA, Horton T, Collins A, Miller DS. Normal caffeine consumption: influence on thermogenesis, and daily energy expenditure in lean and post-
obese human volunteers. Am f Clin Nutr 1989;49:44 50 .

34 Noppa H, Bengtsson C. Obesity in relation to smoking: a population study of women in Göteborg, Sweden. Prev Med 1980;9:534-43. 